\title{
Mesozooplankton size-selectivity and grazing impact on the phytoplankton community of the Prince Edward Archipelago (Southern Ocean)
}

\author{
Renzo Perissinotto
}

Southern Ocean Group, Department of Zoology and Entomology, Rhodes University, Grahamstown 6140, South Africa

\begin{abstract}
Dense phytoplankton blooms are often found during austral summer and autumn in the Prince Edward Archipelago $\left(47^{\circ} \mathrm{S}, 38^{\circ} \mathrm{E}\right)$. These blooms are dominated by the large diatoms Chaetoceros radicans and Rhizosolenia curvata and by the silicoflagellate Dictyocha speculum. Sizeselectivity experiments, using the dominant herbivorous zooplankton found in the area, show that the nano-phytoplankton is preferentially selected by all taxa. Only 2 euphausiid species appear to have a significant $(\mathrm{p}<0.05)$ positive selection for the smaller netplankton $(20$ to $37 \mu \mathrm{m})$. Poor utilization of these diatom blooms is also supported by the results of a comparative study of grazing impact during a bloom (April 1985) and a non-bloom condition (April/May 1989). When phytoplankton biomass is low, the zooplankton community ingests 33 to $48 \%$ of the euphotic zone chlorophyll a per day, or 76 to $81 \%$ of daily primary production. However, during bloom conditions the grazing impact is reduced to only 5 to $10 \%$ of chlorophyll a concentration and 9 to $17 \%$ of primary production per day. Preferential selection for the smaller cells may have an energetic significance as nanoplankton seems to represent a food source of higher nutritional value than bloom-generating diatoms. It is suggested that the bulk of the phytoplankton blooms sinks out of the photic zone and provides an important transfer of biomass from the pelagic to the benthic subsystems.
\end{abstract}

\section{INTRODUCTION}

The marine ecosystem of the Prince Edward Archipelago $\left(47^{\circ} \mathrm{S}, 38^{\circ} \mathrm{E}\right)$ exhibits repeated, seasonal occurrences of phytoplanton blooms, with enhanced primary productivity relative to the surrounding ocean (Allanson et al. 1985, Boden 1988, Perissinotto \& Duncombe Rae 1990). This high production is related to a form of island mass effect that involves the stability of the surface mixed-layer and the availability of reduced forms of nitrogen nutrients (Perissinotto et al. 1990a, b). Both features are locally enhanced by high levels of freshwater run-off from the islands.

The fate of these phytoplankton blooms is largely unknown. However, the presence of a rich benthic community in the inter-island plateau, and the abundance of resting spores in the phytoplankton collections (Fryxell et al. 1981), suggests that most of their biomass may be transferred to the benthic subsystem via sedimentation. Another likely pathway, by which the bloom biomass can be utilised by higher trophic levels, is zooplankton grazing in the upper mixed-layer. The zooplankton community of the Prince Edward Archipelago is relatively rich and comparable in biomass to that of the Antarctic Polar Front (Boden 1988, Perissinotto 1989). However, in the inter-island plateau, where most of the phytoplankton blooms are concentrated, the zooplankton is exposed to high predation pressure by part of the large community of marine and land-based visual predators. This results in zooplankton mass depletion (up to $50 \%$ decrease in biomass $\mathrm{d}^{-1}$ ), especially during daytime when the descent of the vertical migrators is blocked by interaction with the shallow bottom topography of the shelf (Perissinotto 1989).

Preliminary investigations on zooplankton-phytoplankton relationships in the Prince Edward Archipelago have suggested that utilization of the rich phytoplankton blooms by pelagic herbivores may be poor or negligible (Perissinotto \& Boden 1989). The present study was designed to test this hypothesis by means of size-selectivity experiments and by estimating the grazing impact of the local community of zooplankton on the naturally occurring phytoplankton assemblage. 


\section{MATERIALS AND METHODS}

Size-selectivity. Naturally occurring phytoplankton was collected with a submersible pump during the MOES-2 (Marion Off-shore Ecosystem Study) cruise of SA 'Agulhas' to the Prince Edward Archipelago in autumn 1989 (April/May). As chlorophyll a (chl a) concentrations were unusually low, phytoplankton collections were concentrated on $0.2 \mu \mathrm{m}$ Nuclepore filters to an experimental value of about 1.5 to $3.0 \mu \mathrm{g} \mathrm{chl} \mathrm{al^{-1 }}$ (i.e. the normal concentration range for blooms in the area). Three experimental bottles with animals and 2 control bottles with no animals were filled with the phytoplankton mixture and rotated on a plankton wheel (ca $1 \mathrm{rpm}$ ) in the dark, at 9 to $10^{\circ} \mathrm{C}$ for $24 \mathrm{~h}$. Five euphausiids or 10 copepods were incubated in each 21 or 11 experimental bottle, respectively. Duplicate water samples $(100 \mathrm{ml})$ were taken from each bottle at the beginning and end of the incubation for chl $a$ and phaeopigment analysis. Four size-fractions of phytoplankton $(200-20,20-5,5-1$ and $1-0.2 \mu \mathrm{m}$ ) were obtained by multiple serial filtration on a Sartorius Membranfilter column. Pigments from the different filters were extracted overnight at $4{ }^{\circ} \mathrm{C}$ in $10 \mathrm{ml}$ $90 \%$ acetone and concentrations were calculated from the fluorescence readings on a Turner Model 111 fluorometer (Strickland \& Parsons 1968, Conover et al. 1986).

Grazing impact. Zooplankton community grazing was estimated by using the 8 most important taxa (in terms of biomass) encountered in the area. These included the pteropod Limacina sp., the ostracod Conchoecia sp., the copepods Calanus simillimus, Clausocalanus brevipes and Metridia gerlachei, and 3 developmental stages of the euphausiid Euphausia vallentini (adult, calyptopis and furcilia). Two stations of 30 and $36 \mathrm{~h}$ respectively were occupied in the Prince Edward Archipelago during April 1985: Stn A, located over the Natal Bank, and Stn B, located midway between Prince Edward and Marion Island (Fig. 1). In April/May 1989, 2 other stations (E and F), each of $24 \mathrm{~h}$ and corresponding approximately to the sites of 1985 , were investigated. Stns A and E are representative of the islands' shelf as they lie within the $100 \mathrm{~m}$ isobath, while Stns B and F are situated off-shore where the slope falls off very rapidly (Fig. 1). During 1989, depth profiles of conductivity and temperature were measured at $6 \mathrm{~h}$ intervals using a Neil Brown Mk III probe, while only XBT profiles were obtained during April 1985. Discrete samples for chl a analysis were taken every 6 to $12 \mathrm{~h}$ at standard depths (Figs. 2 \& 3 ) with 51 Niskin bottles. Chl a concentrations were obtained by the spectrophotometric method of SCOR/UNESCO (1966). Primary production rates were estimated by ondeck incubation ( $4.5 \mathrm{~h}$ ) at different light levels of $300 \mathrm{ml}$ samples inoculated with 20 to $25 \mu \mathrm{Ci}$ of $\mathrm{NaH}^{14} \mathrm{CO}_{3}$.

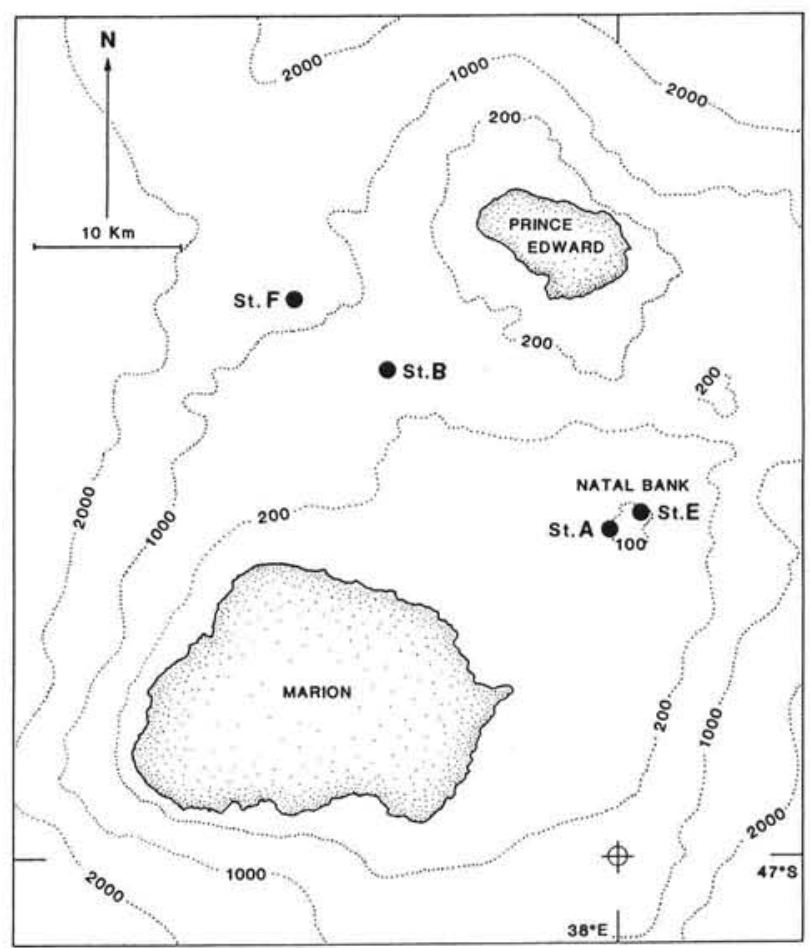

Fig. 1. Position of sampling stations in the Prince Edward Archipelago. Stns A and B were occupied in April 1985, Stns E and F in April/May 1989. Depth contours are in meters

Community feeding impact $\left(F_{1 ;} \mathrm{ng}\right.$ (pigm.) $\mathrm{m}^{-3} \mathrm{~d}^{-1}$ ) can be estimated from the equation:

$$
F_{\mathrm{I}}=\sum_{j=1}^{n}\left(A_{\mathrm{i}} \times I_{\mathrm{i}}\right)
$$

where $A=$ zooplankton abundance (ind. $\left.\mathrm{m}^{-3}\right) ; I=$ ingestion rate (ng (pigm.) ind..$\left.^{-1} \mathrm{~d}^{-1}\right)$; and the subscript $i$ $=$ the $i$ th taxon of the zooplankton community. Under the assumption of steady state $(\mathrm{d} P / \mathrm{d} t=0)$, the ingestion rate is given by the product of ingested pigment, $P$ (ng (pigm.) ind. ${ }^{-1}$ ), and the gut evacuation rate, $K\left(\mathrm{~d}^{-1}\right)$, where $P$ is the sum of the pigment measurable in the gut, $G$, and the undetectable fraction of the pigment that has been absorbed (digested), $b$. Since $b$ can be expressed as: $b=b^{\prime} P$, where $b^{\prime}$ represent a nondimensional index for the loss of pigment in the digestive process, then, substituting, the ingestion rate equation can be written as (Wang \& Conover 1986):

$$
I=K G /\left(1-b^{\prime}\right)
$$

Due to the large variability in zooplankton abundance and feeding activity during a diurnal cycle, integrated values (over a $24 \mathrm{~h}$ period) of both gut pigment contents and abundance are probably the most appropriate for the calculation of daily impact:

$$
G=1 / t \int_{0}^{24} g \mathrm{~d} t, \quad A=1 / t \int_{0}^{24} a \mathrm{~d} t
$$


The community feeding impact can then be rewritten as:

$$
F_{1}=\sum_{i=1}^{n}\left(K_{\mathrm{i}} / t\right) /\left(1-b_{\mathrm{i}}^{\prime}\right) \int_{0}^{24}\left(a_{\mathrm{i}} \times g_{\mathrm{i}}\right) \mathrm{d} t
$$

The following is a description of the methods used to estimate the parameters $A, G, K$, and $b^{\prime}$.

Zooplankton abundance $(\boldsymbol{A})$. Zooplankton was collected at $3 \mathrm{~h}$ intervals by means of oblique Bongo (200 $\mu \mathrm{m}$ mesh) tows to depths of about $300 \mathrm{~m}$ during the day and $100 \mathrm{~m}$ during the night. One sample from each tow was preserved with $5 \%$ formalin for quantitative abundance analysis, while the second sample was used for measurements of gut pigment content. A closed, 21 volume cod-end was fitted to the net selected for the collection of material for gut pigment analysis. From the preserved samples the major zooplankton taxa were counted in subsamples of 0.1 to 0.2 of the original samples obtained with the Wiborg's modified whirling apparatus (Kott 1953). The biomass of individual taxa was estimated from the dry weight $\left(60^{\circ} \mathrm{C}\right)$ of 3 replicate sets of 50 to 300 specimens each (depending upon the size of the taxon considered).

Gut pigment content $(G)$. Zooplankton for measurement of gut pigment content were sorted immediately after capture. The cod-end contents were poured onto a $200 \mu \mathrm{m}$ sieve from which individuals were gently picked using jeweller's forceps (Peterson et al. 1990). Picking was carried out during a period of 5 to $10 \mathrm{~min}$; Peterson et al. (1990) have shown that defecation on the sieve does not occur within this time scale. Five to 10 individuals were picked per taxon, placed in a plastic centrifuge tube with $5 \mathrm{ml} 90 \%$ acetone, homogenised with a glass rod, and stored at $-20^{\circ} \mathrm{C}$ for $12 \mathrm{~h}$. After centrifugation (5000 rpm) the pigment content of the acetone extract was measured with a Turner 111 fluorometer, before and after acidification (Mackas \& Bohrer 1976). The chl $a$ and phaeopigment contents per individual were calculated using the formulas of Strickland \& Parsons (1968) modified by Conover et al. (1986):

$\left[\mu \mathrm{g} \mathrm{chl} a\right.$ ind $\left.^{-1}\right]=\{F d[\tau /(\tau-1)](R b-R a)\} / n$

$\left[\mu \mathrm{g}\right.$ Phaeo ind.$\left.^{-1}\right]=\{\tau F d[(\tau R a-R b) /(\tau-1)] 0.66\} / n$

where $F d=$ the fluorometer door factor; $R b$ and $R a=$ the fluorescence readings before and after acidification, respectively; $\tau=$ the ratio $R a / R b$ for pure chlorophyll; $n=$ number of animals per sample; and $0.66=$ the molecular weight ratio of phaephorbide $a$ to chl a.

The gut pigment levels of Clausocalanus brevipes, Metridia gerlachei, Euphausia vallentini (adults and furcilia) and Limacina sp. were not measured in 1985. However, for the other taxa (Calanus simillimus, E. vallentini calyptopis and Conchoecia sp.) data on gut pigment contents were available in both years. For these taxa, differences in pigment levels between the bloom (1985) and non-bloom conditions (1989) were constant, with values always much higher in 1985 than in 1989. Therefore, to estimate gut pigment contents for the species for which these were not available in 1985 , conversion factors were used. The community grazing impact for April 1985 was then obtained by multiplying the gut pigment levels of $C$. brevipes, $M$. gerlachei, E. vallentini and Limacina sp. measured in 1989 by an average factor of 8.9 for the Natal Bank and 11.7 for the offshore samples.

Gut evacuation rate $(\boldsymbol{K})$. Estimates of this parameter were obtained only during April/May 1989. Freshly caught zooplankton were placed into $10 \mathrm{l}$ containers filled with $0.2 \mu \mathrm{m}$ filtered seawater. As temperature is a very important factor affecting evacuation rate (Dam \& Peterson 1988), containers with experimental animals were kept in a cold room $\left(9\right.$ to $10^{\circ} \mathrm{C}$ ), at ambient temperature. Gut pigment contents of zooplankton were then monitored over time. For all copepods, the ostracod Conchoecia sp. and the pteropod Limacina sp., measurements were taken for $1 \mathrm{~h}$ at intervals of 0 , $5,10,20,30,40$, and $60 \mathrm{~min}$. The choice of estimating $K$ from frequent measurements during the first hour of starvation was made because it is becoming evident that after this period there are significant differences in gut evacuation rate between starved and continuously feeding animals (Baars \& Helling 1985, Kiørboe \& Tiselius 1987, Dam \& Peterson 1988). Euphausiids tend to retain food in their guts for periods of up to $2 \mathrm{~d}$, unless they are kept under continuous feeding conditions (Willason \& Cox 1987). Thus, to determine their gut evacuation rate, charcoal particles $(<100 \mu \mathrm{m})$ were added to the filtered seawater in the experimental containers. The role of these particles is to displace previously ingested food. Gut pigment contents were then monitored for $12 \mathrm{~h}$ at intervals of $0,0.5,1,2,4,8$ and $12 \mathrm{~h}$ after collection. With a constant evacuation rate, the amount of pigment in the gut of zooplankton grazers is related to time without food as:

$$
G_{t}=G_{0} \exp (-K t)
$$

Here $G_{\mathrm{o}}$ and $G_{t}$ represent the amount of gut pigment measured at the beginning of the starvation period and at time $t$, respectively. Taking the logarithms, $K\left(\mathrm{in} \mathrm{h}^{-1}\right)$ can be calculated from the plot of gut pigment concentration against time of incubation:

$$
K=\ln \left(G_{\mathrm{o}} / G_{t}\right) / t
$$

Since no gut evacuation rate measurements were made in April 1985, the values obtained during 1989 were used to calculate the grazing impact for both periods.

Absorbed pigments $\left(b^{\prime}\right)$. Loss of pigments by absorption/destruction was estimated from measurements of 
decrease in pigment content of grazing bottles and increase in gut pigment levels of animals incubated in these bottles. Animals starved for 6 to $12 \mathrm{~h}$ were fed concentrated phytoplankton mixtures ( 1.5 to $3.0 \mu \mathrm{g} \mathrm{l}^{-1}$ ) in $1 \mathrm{l}$ bottles. Pigments may be lost from the grazing bottles either by digestion to non-fluoroscent residues or by disintegration and leakage of faecal pellets. To exclude losses due to disintegration of faeces, incubations were carried out over short times $(<30 \mathrm{~min}$ for copepods and $<60 \mathrm{~min}$ for euphausiids) and pigment levels measured before defecation (Dagg 1983, Kiørboe \& Tiselius 1987). At the end of the incubation, the grazing bottle contents were filtered onto a $60 \mu \mathrm{m}$ Nitex filter to check for faecal production. On no occasion were faeces recorded. Four replicate samples $(100 \mathrm{ml})$ from both experimental and control bottles were filtered onto $0.2 \mu \mathrm{m}$ Nuclepore filters from which pigment levels were measured using the technique outlined above.

Calculations of the fractional loss of pigment, for each taxon examined, were made using the relation:

$$
b^{\prime}(\%)=\left\{\left[\left(G_{\mathrm{t}}-P_{b}\right) / P\right]-1\right\} 100
$$

where $G_{t}=$ the gut pigment content ind ${ }^{-1}$ at the end of the incubation; $P_{b}=$ background fluorescence ind ${ }^{-1}$; and $P=$ total amount of pigment ingested ind $^{-1} . P$ is derived from the difference between control $\left(C_{t}\right)$ and experimental $\left(E_{t}\right)$ bottles at the end of the incubation, divided by (n) the number of animals in the grazing bottles: $P=\left(C_{t}-E_{t}\right) / n$.

Experiments were carried out with Calanus simillimus, Metridia gerlachei and the 3 stages of Euphausia vallentini. The percentage of pigments absorbed (digested, $b^{\prime}$ ) by Clausocalanus brevipes, Conchoecia sp. and Limacina sp. was assumed to be equal to the average of the values derived from the conversion efficiency measurements of the other 4 taxa (see Table 4). This assumption was based on the fact that the percentage of lost pigments seems to be independent of the type of grazer (Dam \& Peterson 1988).

\section{RESULTS}

\section{Phytoplankton production}

In April/May 1985, chl a concentrations attained values indicative of bloom conditions in the area. Typically, on the Natal Bank surface levels were $>2 \mathrm{mg}$ $\mathrm{m}^{-3}$, while at the offshore station the highest values were about half this (Fig. 2). The difference between the 2 stations is reflected in the depth of the thermocline, ca 30 to $40 \mathrm{~m}$ and ca 80 to $100 \mathrm{~m}$ on the Natal Bank and offshore, respectively (Fig. 2). Conversely, no difference in chl a concentration between the 2 stations was evident during April/May 1989, and low values $\left(<0.3 \mathrm{mg} \mathrm{m}^{-3}\right)$ were recorded at both sites (Fig. 3). The thermocline was deeper than in 1985 and positioned at ca 60 to $70 \mathrm{~m}$ on the Natal Bank and at ca 90 to $110 \mathrm{~m}$ offshore (Fig. 3). Phytoplankton production during the 2 investigations followed the same pattern described for $\mathrm{chl}$ a. In 1985, maximum values of ${ }^{14} \mathrm{C}$ uptake by the phytoplankton community was between 0.7 (offshore) and $1.2 \mathrm{mg} \mathrm{C} \mathrm{m}^{-3} \mathrm{~h}^{-1}$ (Natal Bank), while in 1989 values never exceeded $0.4 \mathrm{mg} \mathrm{C} \mathrm{m}^{-3} \mathrm{~h}^{-1}$ (Figs. 2 \& 3).

\section{Size-selectivity}

During April/May 1989 the phytoplankton community of the Prince Edward Archipelago was dominated by the nano-size fraction $(20-1 \mu \mathrm{m})$, which represented $50.2 \pm 2.8 \%$ of the total chl $a$. The net- $(200-20 \mu \mathrm{m})$ and picoplankton $(1-0.2 \mu \mathrm{m})$ constituted $35.8 \pm 6.3$ and $14.3 \pm 3.1 \%$ of the total, respectively. The major components of the zooplankton community showed a preferential selection for the nano-size fractions (Table 1).

Of the 5 zooplankton species used in the experiments (the copepods Calanus simillimus and Metridia gerlachei and the euphausiids Euphausia vallentini, E. similis var. armata and Thysanoessa vicina) only 2 euphausiids, $E$. vallentini and $T$, vicina, appeared to have a significant impact on the smaller netphytoplankton $(37-20 \mu \mathrm{m})$.

\section{Zooplankton abundance}

The 8 mesozooplankton taxa considered in the estimation of the community grazing impact are usually among the most abundant in the area (Boden \& Parker 1986, Perissinotto 1989). During the investigations these 8 taxa together constituted between 25 and $50 \%$ in number, and 62 to $78 \%$ by weight (DW) of the total catch (Table 2). On both occasions the group was numerically dominated by Calanus simillimus, while Euphausia vallentini (all stages combined) was always the largest contributor to total biomass. During April 1989, abundances were generally higher than in 1985. Values recorded on the former investigation were up to 3.5 times (C. simillimus) those found in April 1985. Apart from Limacina sp. and Clausocalanus brevipes, all the other taxa were present in higher concentrations at the offshore stations than on the Natal Bank (Table 2).

\section{Gut pigment content}

All zooplankton taxa showed diel feeding rhythms at both stations and during both years (Figs. $4 \& 5$ ). The 


\section{NATAL BANK 1985}

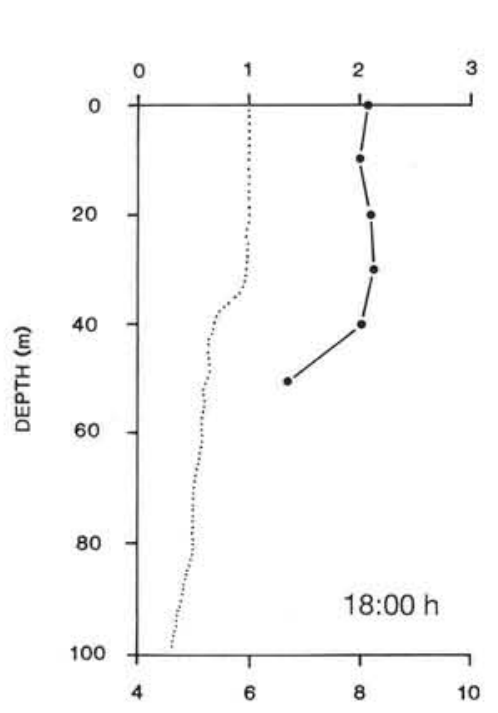

POTENTIAL TEMPERATURE $\left({ }^{\circ} \mathrm{C}\right)$
CHLOROPHYLL a $\left(\mathrm{mg} \times \mathrm{m}^{-3}\right)$
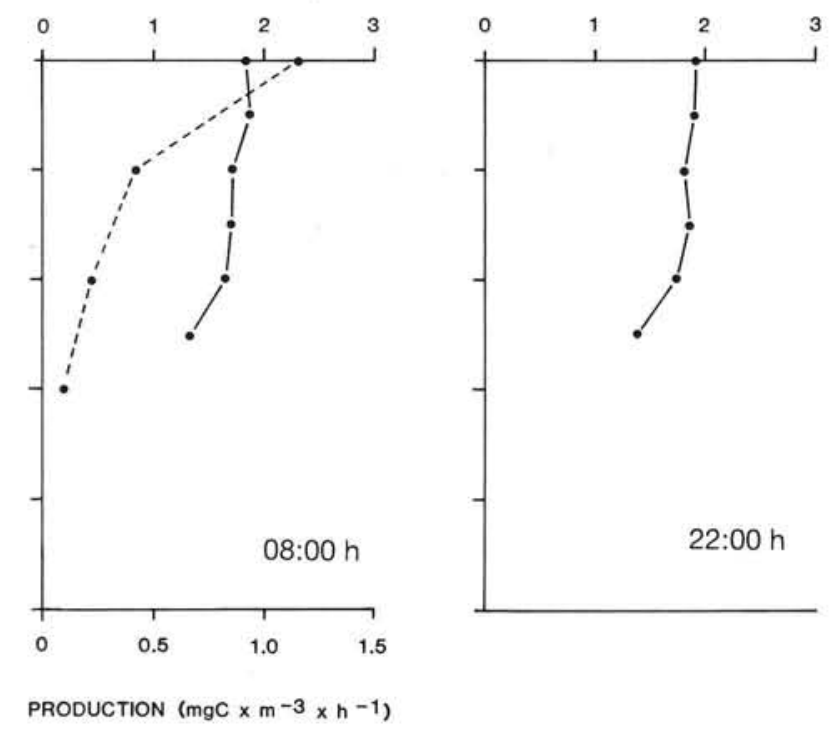

CHLOROPHYLL a $\left(\mathrm{mg} \times \mathrm{m}^{-3}\right)$

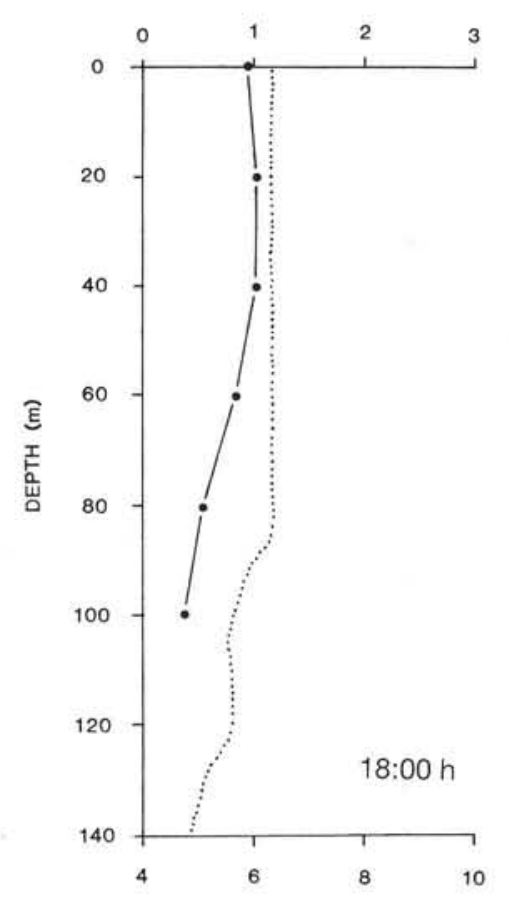

POTENTIAL TEMPERATURE $\left({ }^{\circ} \mathrm{C}\right)$
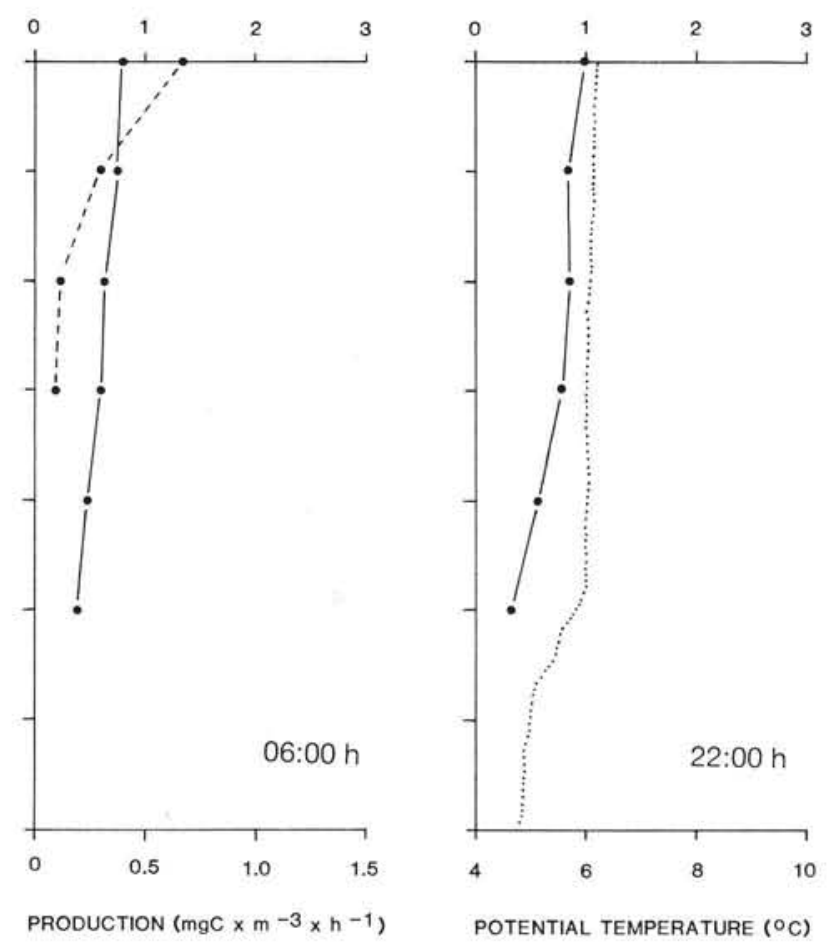

Fig. 2. Vertical profiles of temperature $(\cdots \cdot)$, chlorophyll a $(\bullet \bullet)$ and phytoplankton production $(\bullet \bullet \bullet)$ for the April 1985 survey 
NATAL BANK 1989

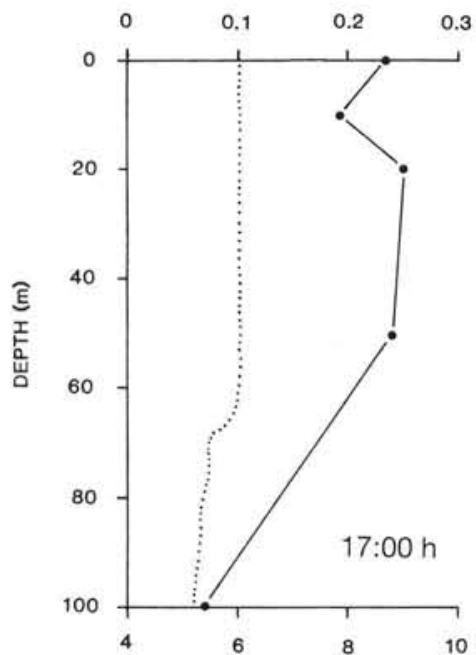

OFFSHORE 1989

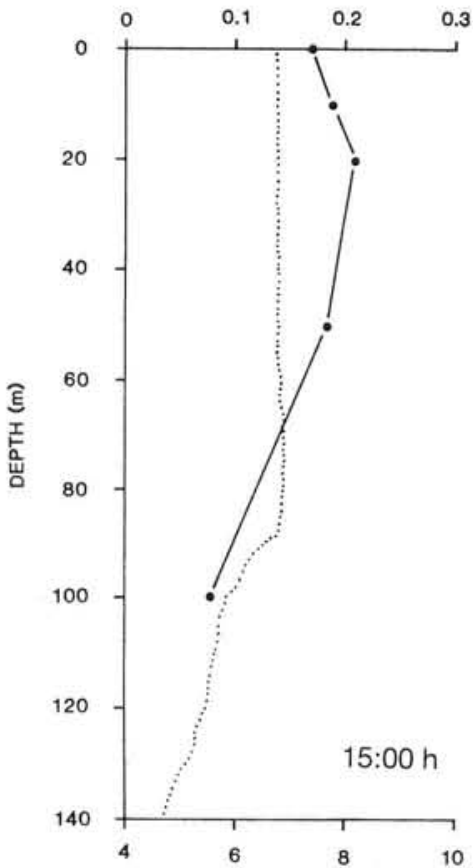

PRODUCTION $\left(\mathrm{mgC} \times \mathrm{m}^{-3} \times \mathrm{h}^{-1}\right)$
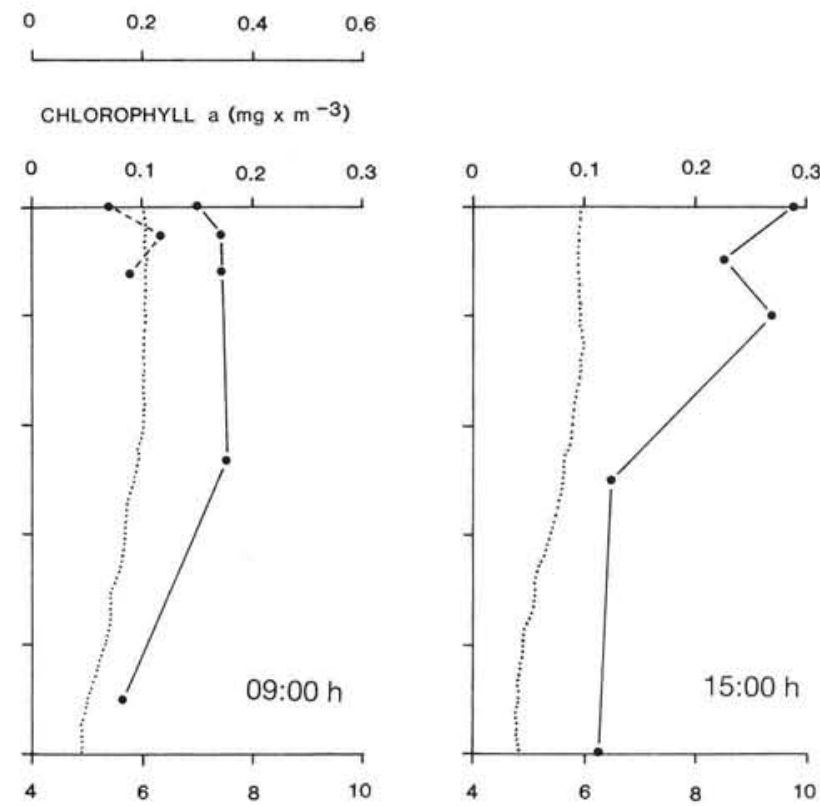

POTENTIAL TEMPERATURE $\left({ }^{\circ} \mathrm{C}\right)$

PRODUCTION (mgC $\left.\times \mathrm{m}^{-3} \times \mathrm{h}^{-1}\right)$

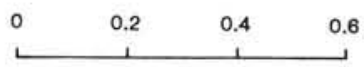

CHLOROPHYLL a $\left(\mathrm{mg} \times \mathrm{m}^{-3}\right)$
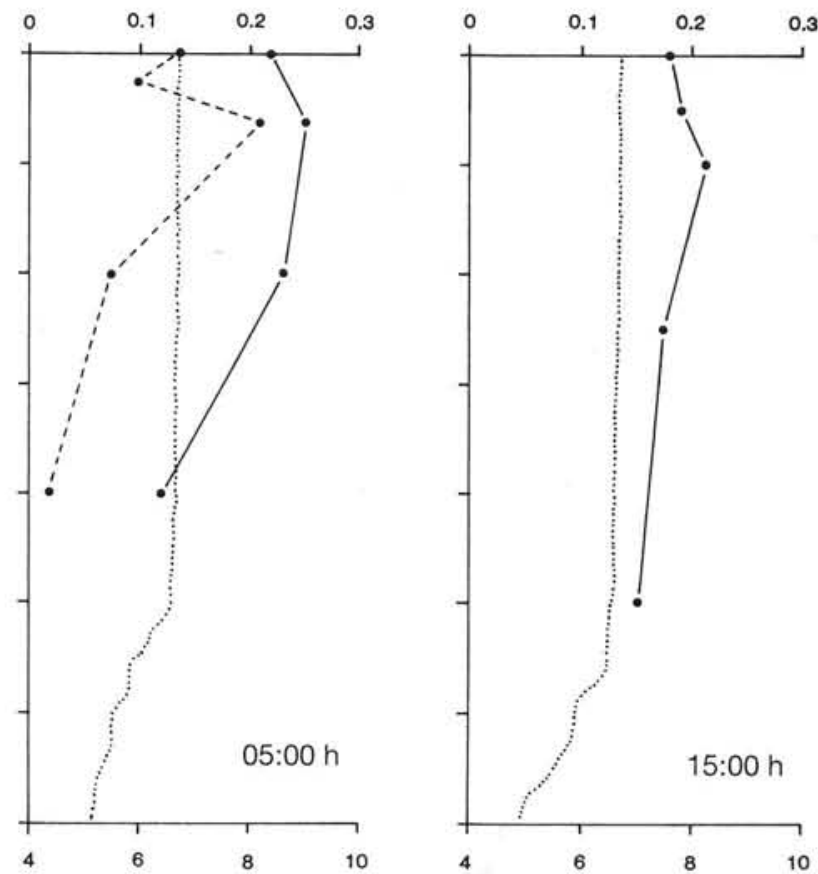

POTENTIAL TEMPERATURE $\left({ }^{\circ} \mathrm{C}\right)$

Fig. 3. Vertical profiles of temperature $(\cdots \cdot)$, chlorophyll a $(\bullet \bullet)$ and phytoplankton production $(\bullet \bullet \bullet)$ for the April/May 1989 survey 
Table 1. Analysis ( $t$-test, independent samples) of the size-selectivity of naturally occurring phytoplankton by the most important components of the zooplankton community of the Prince Edward Island seas (April 1989). Control and experimental values are expressed as mean \pm standard deviation. $\mathrm{ns}=$ not significant

\begin{tabular}{|c|c|c|c|c|c|}
\hline $\begin{array}{l}\text { Size fract. } \\
(\mu \mathrm{m})\end{array}$ & $\begin{array}{c}\text { Control } \\
\left(\mu \mathrm{g} \text { pigm. } 1^{-1}\right)\end{array}$ & $\begin{array}{c}\text { Experiment } \\
\left(\mu \mathrm{g} \text { pigm. } 1^{-1}\right)\end{array}$ & $t$-stat. & $\begin{array}{l}\text { Signif. } \\
\text { (p) }\end{array}$ & $\begin{array}{c}\mathrm{N} \\
\text { (pooled) }\end{array}$ \\
\hline \multicolumn{6}{|c|}{ Thysanoessa vicina } \\
\hline $200-37$ & $0.56 \pm 0.16$ & $0.50 \pm 0.17$ & 0.45 & ns & 12 \\
\hline $37-20$ & $0.45 \pm 0.03$ & $0.27 \pm 0.05$ & 7.01 & 0.001 & 12 \\
\hline $20-1$ & $3.19 \pm 0.54$ & $1.69 \pm 0.88$ & 2.74 & 0.021 & 12 \\
\hline $1-0.2$ & $0.43 \pm 0.21$ & $0.60 \pm 0.34$ & 1.83 & ns & 12 \\
\hline \multicolumn{6}{|c|}{ Euphausia vallentini } \\
\hline $200-37$ & $0.47 \pm 0.03$ & $0.33 \pm 0.09$ & 3.06 & 0.012 & 12 \\
\hline $37-20$ & $0.33 \pm 0.08$ & $0.17 \pm 0.08$ & 3.17 & 0.001 & 12 \\
\hline $20-1$ & $1.85 \pm 0.35$ & $1.13 \pm 0.34$ & 3.43 & 0.003 & 12 \\
\hline $1-0.2$ & $0.54 \pm 0.32$ & $0.32 \pm 0.29$ & 1.20 & ns & 12 \\
\hline \multicolumn{6}{|c|}{ E. similis var, armata } \\
\hline $200-20$ & $0.29 \pm 0.12$ & $0.30 \pm 0.05$ & 0.38 & ns & 16 \\
\hline $20-5$ & $0.30 \pm 0.09$ & $0.16 \pm 0.07$ & 3.35 & 0.009 & 16 \\
\hline $5-1$ & $0.29 \pm 0.15$ & $0.31 \pm 0.18$ & 0.31 & ns & 16 \\
\hline $1-0.2$ & $0.22 \pm 0.10$ & $0.19 \pm 0.07$ & 0.61 & ns & 15 \\
\hline \multicolumn{6}{|c|}{ Calanus simillimus } \\
\hline $200-20$ & $0.52 \pm 0.07$ & $0.50 \pm 0.06$ & 0.56 & ns & 16 \\
\hline $20-5$ & $0.45 \pm 0.08$ & $0.21 \pm 0.17$ & 3.66 & 0.048 & 16 \\
\hline $5-1$ & $0.26 \pm 0.05$ & $0.16 \pm 0.04$ & 4.15 & 0.001 & 16 \\
\hline $1-0.2$ & $0.18 \pm 0.06$ & $0.14 \pm 0.07$ & 1.18 & ns & 16 \\
\hline \multicolumn{6}{|c|}{ Metridia gerlachei } \\
\hline $200-20$ & $0.55 \pm 0.04$ & $0.47 \pm 0.14$ & 1.52 & $\mathrm{~ns}$ & 18 \\
\hline $20-5$ & $0.39 \pm 0.12$ & $0.20 \pm 0.11$ & 3.38 & 0.018 & 18 \\
\hline $5-1$ & $0.38 \pm 0.24$ & $0.35 \pm 0.27$ & 0.21 & ns & 18 \\
\hline $1-0.2$ & $0.13 \pm 0.07$ & $0.23 \pm 0.16$ & 1.61 & ns & 18 \\
\hline
\end{tabular}

pattern of variation in gut pigments during the $24 \mathrm{~h}$ cycles appeared to be predominantly unimodal, but in a few cases (Conchoecia sp., 1985; Euphausia vallentini adults, 1989; Limacina sp., 1989) some evidence of bimodality was also recorded. The highest gut pigment levels were always found at night, but, while on the Natal Bank peak values occurred in the earlier part of the night (18:00 to $22: 00 \mathrm{~h})$, in offshore waters there was a consistent time-lag and gut pigment maxima were shifted to the pre-dawn period (01:00 to $4: 00 \mathrm{~h}$ ). In most cases during 1989, zooplankton had higher average gut pigment contents on the Natal Bank than in offshore waters (Fig. 5). This pattern, however, was not evident in the results of the 1985 investigation (Fig. 4). Within the same taxa, large differences were observed in the levels of gut pigment between the period of phytoplankton bloom (April 1985) and the non-bloom conditions (April/May 1989). The largest difference was recorded for the ostracod Conchoecia sp. which during 1985 showed pigment concentrations 16 to 22 times higher than in 1989. For Calanus simillimus and E. vallentini calyptopis differences between the 2 periods ranged from 5 to 9 and from 3 to 5 times, respectively (Figs. $4 \& 5$ ). The average difference for the 3 taxa pooled was between 8 and 12 times for the Natal Bank and the offshore stations, respectively.

\section{Gut evacuation rate}

In all cases, negative exponential models (Table 3) provided the best fit to the decline in gut pigment contents during the non-feeding period. The highest evacuation rate constants $(K)$ were found for the 3 copepod species with values of $1.96,1.75$ and $1.41 \mathrm{~h}^{-1}$ for Calanus simillimus, Metridia gerlachei and Clausocalanus brevipes, respectively. The corresponding gut turnover times (reciprocal of $K$ ) were $0.51,0.57$ and $0.71 \mathrm{~h}$. All the other taxa had much longer gut turnover times (i.e. $K<1$; Table 3 ).

\section{Absorbed pigments}

Percentage conversion efficiency calculated for the 3 developmental stages of Euphausia vallentini, and the copepods Calanus simillimus and Metridia gerlachei, ranged from a minimum of ca $52 \%$ to a maximum of ca 

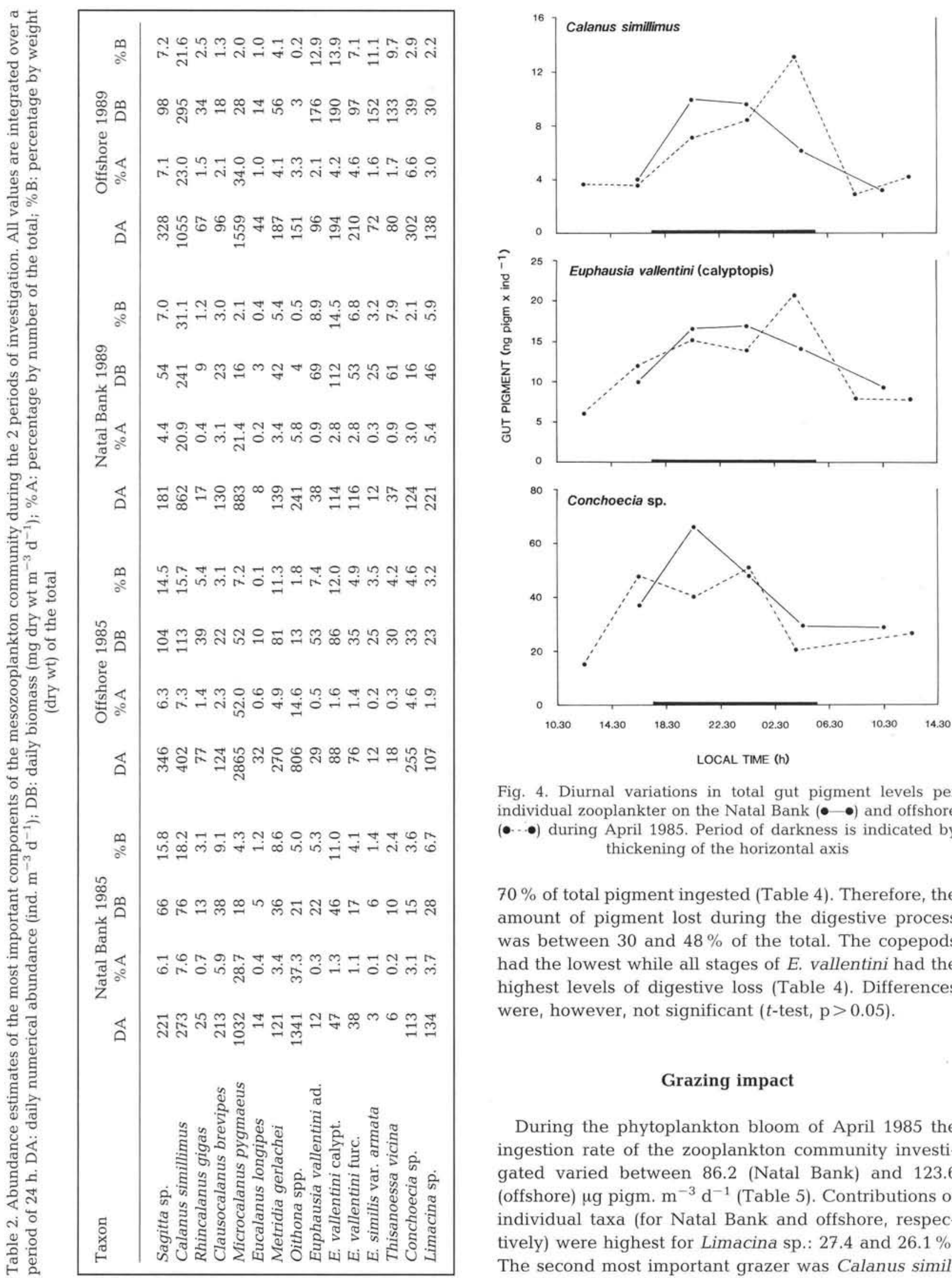

Fig. 4. Diurnal variations in total gut pigment levels per individual zooplankter on the Natal Bank $(\bullet \bullet)$ and offshore $(\bullet \bullet)$ during April 1985. Period of darkness is indicated by thickening of the horizontal axis

$70 \%$ of total pigment ingested (Table 4 ). Therefore, the amount of pigment lost during the digestive process was between 30 and $48 \%$ of the total. The copepods had the lowest while all stages of $E$. vallentini had the highest levels of digestive loss (Table 4). Differences were, however, not significant ( $t$-test, $\mathrm{p}>0.05)$.

\section{Grazing impact}

During the phytoplankton bloom of April 1985 the ingestion rate of the zooplankton community investigated varied between 86.2 (Natal Bank) and 123.6 (offshore) $\mu \mathrm{g}$ pigm. $\mathrm{m}^{-3} \mathrm{~d}^{-1}$ (Table 5). Contributions of individual taxa (for Natal Bank and offshore, respectively) were highest for Limacina sp.: 27.4 and $26.1 \%$. The second most important grazer was Calanus simil- 

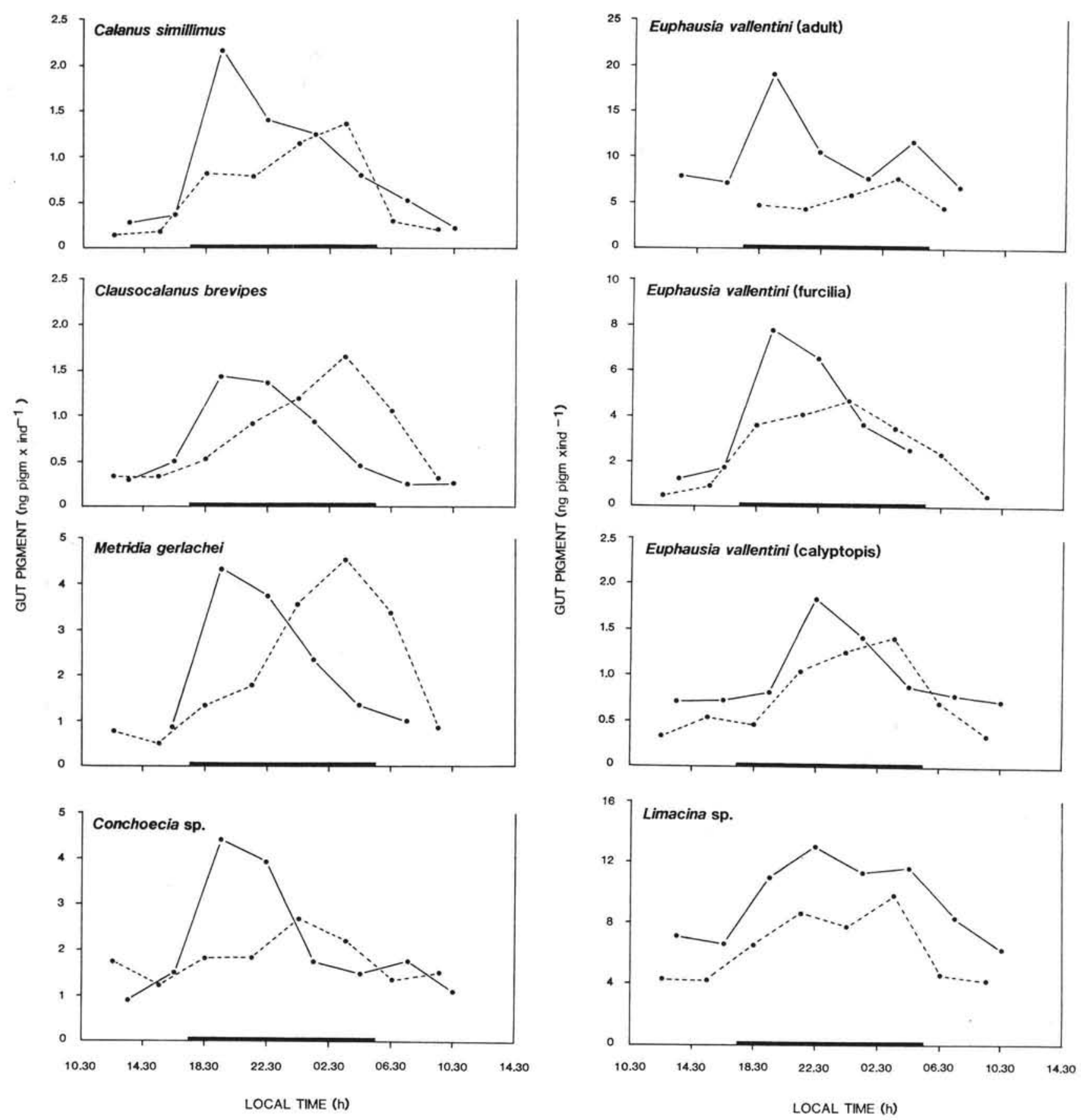

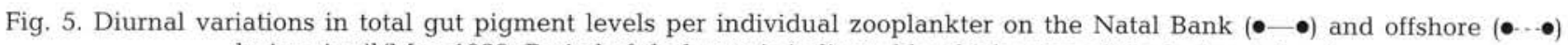
during April/May 1989. Period of darkness is indicated by thickening of the horizontal axis

limus with 25.0 and $21.2 \%$ of total pigment ingested. The whole community examined had a grazing impact of only 4.9 and $9.9 \%$ of the euphotic zone-integrated phytoplankton biomass (Table 5). For the same stations, the impact on the integrated phytoplankton production (given a C:chl ratio of 25; Perissinotto \& Bailey unpubl.) was 8.8 and $17.4 \%$, respectively. The com- munity grazing impact was much higher during April/ May 1989 (Table 5). On this occasion the 8 zooplankton taxa consumed 33.4 (Natal Bank) to $47.7 \%$ (offshore) of the phytoplankton biomass and 75.6 to $81.3 \%$ of primary production per day. The most important contributor to the daily ingestion in this case was $C$. simillimus which alone accounted for 40.2 and $33.0 \%$ of the total. 
Table 3. Exponential models of the gut evacuation rate for the zooplankton taxa investigated at the Prince Edward Islands (April/ May 1989). K: gut evacuation rate constant

\begin{tabular}{|c|c|c|c|c|}
\hline Taxon & Model fit & $\mathrm{N}$ & $\mathrm{R}^{2}$ & $K\left(\mathrm{~h}^{-1}\right)$ \\
\hline Calanus simillimus & $Y=\exp (0.77-0.03)$ & 14 & 0.85 & 1.96 \\
\hline Clausocalanus brevipes & $Y=\exp (-7.67-0.02)$ & 14 & 0.77 & 1.41 \\
\hline Metridia gerlachei & $Y=\exp (2.17-0.03)$ & 14 & 0.93 & 1.75 \\
\hline Euphausia vallentini ad. & $Y=\exp (1.35-1.70)$ & 14 & 0.91 & 0.59 \\
\hline E. vallentini cal. & $Y=\exp (1.30-1.24)$ & 14 & 0.91 & 0.68 \\
\hline E. Vallentini fur. & $Y=\exp (0.45-1.67)$ & 14 & 0.79 & 0.81 \\
\hline Limacina sp. & $Y=\exp (6.77-0.01)$ & 20 & 0.68 & 0.98 \\
\hline Conchoecia sp. & $Y=\exp (0.46-0.01)$ & 20 & 0.62 & 0.97 \\
\hline
\end{tabular}

Table 4. Estimation of the molar conversion efficiency of chlorophyll a to phaeophorbide $a$ for some of the taxa investigated during April/May 1989. All values are expressed as mean \pm standard deviation

\begin{tabular}{|lccc|}
\hline Taxon & $\begin{array}{c}\text { Gut pigm. content } \\
\text { (ng pigm. ind. }{ }^{-1} \text { ) }\end{array}$ & $\begin{array}{c}\text { Pigm. ingested } \\
\text { (ng pigm. ind. }{ }^{-1} \text { ) }\end{array}$ & $\begin{array}{c}\text { Conversion } \\
\text { efficiency (\%) }\end{array}$ \\
\hline Calanus simillimus & $1.69 \pm 0.34$ & $2.38 \pm 0.19$ & $70.3 \pm 8.7$ \\
Metridia gerlachei & $1.87 \pm 0.55$ & $2.82 \pm 0.31$ & $65.0 \pm 12.4$ \\
Euphausia vallentini ad. & $3.15 \pm 1.18$ & $5.62 \pm 0.48$ & $54.7 \pm 16.3$ \\
E. vallentini cal. & $2.73 \pm 0.78$ & $5.17 \pm 0.93$ & $51.8 \pm 5.7$ \\
E. vallentini fur. & $2.87 \pm 0.84$ & $4.87 \pm 0.58$ & $57.7 \pm 10.4$ \\
\hline
\end{tabular}

\section{DISCUSSION}

The results of the size-selectivity experiments show that all zooplankton taxa preferentially select the nanoplankton, while only the euphausiids Euphausia vallentini and Thysanoessa vicina also have positive selection for the net size-class (Table 1). These experiments were carried out in April/May 1989, when no phytoplankton blooms occurred in the area. During this period the nanoplankton was also the dominant fraction of the phytoplankton biomass with ca $50 \%$ of the total, followed by net- (ca $36 \%$ ) and picoplankton (ca $14 \%$ ). Therefore, the observed positive selection of zooplankton for the nano size-class may suggest a case of preferential feeding on the biomass peak. However, feeding models of passive selection based on particle size and abundance have been largely dismissed (Koehl \& Strickler, 1981, Huntley et al. 1983, Stuart 1989) and seem to apply only to mixtures where there are no differences in food quality between particles (Conover \& Mayzaud 1984). Also, other investigations in the Prince Edward Islands area have suggested that even during phytoplankton blooms, when the netphytoplankton constitutes the biomass peak, a positive selection for the smaller size fractions persists (Perissinotto \& Boden 1989).

It is likely that preconditioning of the zooplankton by their natural food supply is involved. The zooplankton assemblage of the island seas has no endemic compo- nents and exibits a highly variable structure, which is the result of recruitment from short-term advection of oceanic waters by the Antarctic Circumpolar Current (Boden \& Parker 1986, Perissinotto 1989). The subantarctic phytoplankton around the archipelago is typically dominated by the nano size-class (ca 80 and $90 \%$ of total biomass and production respectively; El Sayed et al. 1979, Weber \& El Sayed 1987) while the island blooms represent an exception. The typical size structure of the cells during a bloom, such as the one investigated in 1985 , shows that ca $80 \%$ of total biomass is represented by netplankton, while nanoplankton accounts for only ca $20 \%$ of the total (El Sayed et al. 1979, Perissinotto \& Boden 1989). Zooplankton, therefore, may not be able to acclimate to this unusual food resource within the advection time scale.

Inefficient utilization of bloom phytoplankton is corroborated by the comparative study of zooplankton grazing during bloom and non-bloom conditions. Estimated grazing rates, for the 8 zooplankton taxa here examined, show that when phytoplankton biomass is low zooplankton ingests an amount of chl a per day equivalent to between 33 and $48 \%$ of the average concentration in the euphotic zone, or 76 to $81 \%$ of daily primary production (Table 5). However, during conditions of phytoplankton bloom the zooplankton grazing impact becomes small and only 5 to $10 \%$ of the chl a concentration, or 9 to $17 \%$ of daily primary production, is consumed per day. 


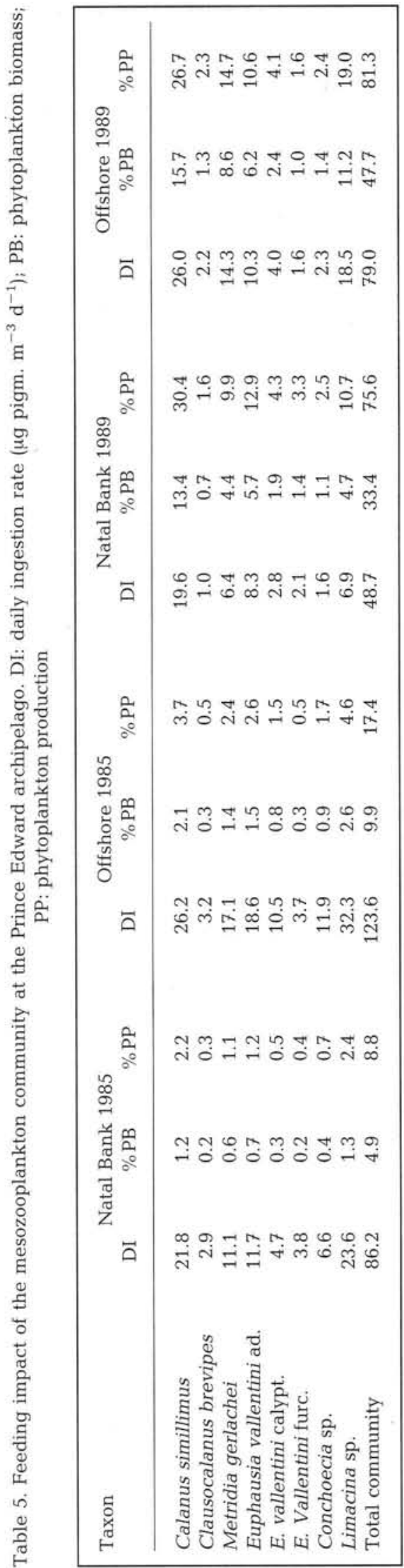

Although not all numerically dominant zooplankton taxa were included in this grazing budget, the proportion examined accounts for ca 75 to $85 \%$ of the total herbivore/omnivore mesozooplankton biomass of the Prince Edward Archipelago (Table 2). The tiny Microcalanus pygmaeus and Oithona spp. were the most numerous copepods, especially during April 1985, but in terms of biomass they represented together only 3 to $10 \%$ of the total. Also, their size suggests that they would, in any event, be unable to ingest the large phytoplankton cells and chains that form the bulk of the blooms.

It could be argued that a more serious source of error, affecting the calculated grazing impact, may be due to the lack of measurements of clearance rate constants $(K)$ in the zooplankton of April 1985. Indeed, while in April/May 1989 estimates of grazing impact were made by in situ, simultaneous determination of zooplankton gut evacuation rates, pigment contents and absorption levels (as recommended by Wang \& Conover 1986 and Dagg \& Walser 1987), no measurements of gut evacuation rates were carried out in 1985. The response of zooplankton gut evacuation rates to changes in ambient food concentration is still largely undetermined (Wang \& Conover 1986, Head \& Harris 1987). However, there is some evidence that the residence time of food in the gut may decrease (i.e. evacuation rate increases) as food concentration increases (Dagg \& Walser 1987, Tsuda \& Nemoto 1987). Thus, in this study, by using the clearance rate constants obtained in 1989 (low chl a levels) to calculate the grazing rates for April 1985 (bloom conditions), the values of community impact for the latter occasion could have been significantly underestimated. Nevertheless, even by assuming that gut evacuation rates during the bloom were twice as high as during the non-bloom conditions (i.e. feeding rate values were doubled), the resulting community grazing impact would still be low.

Thus, both size-selectivity results and estimates of community grazing indicate that the phytoplankton blooms occurring in the Prince Edward Archipelago may not represent a favourable food environment for the local zooplankton. Apart from reasons of food preconditioning, this apparent paradox may require some considerations on the structure of the phytoplankton community of these blooms, and on the feeding habits of the major zooplankton groups found in the area.

The dominance of net size cells in the phytoplankton blooms of the island seas is due to the presence of large concentrations of chains of Chaetoceros spp. or long cells of Rhizosolenia spp. (Table 6). Blooms of Chaetoceros radicans in the Prince Edward Archipelago have been repeatedly found during April 1976 (El Sayed et al. 1979), May and November 1983 (Allanson et al. 1985) and April/May 1987 (Boden 
Table 6. Phytoplankton taxa encountered during April 1985 in the Prince Edward Archipelago. D: dominant, A: abundant, C: common, R: rare. NB: Natal Bank; OS: offshore

\begin{tabular}{|c|c|c|c|c|c|}
\hline Taxon & NB & OS & Taxon & NB & OS \\
\hline Diatoms & & & Navicula distans & $\mathrm{R}$ & - \\
\hline Psammodiscus nitidus & $\mathrm{R}$ & - & Pleurosigma directum & $\mathrm{C}$ & $\mathrm{C}$ \\
\hline Thalassiosira eccentrica & $\mathrm{C}$ & A & Trepidoneis antarctica & $\mathrm{R}$ & - \\
\hline T. leptopus & $\mathrm{R}$ & - & Pseudoeunotia doliolus & $\mathrm{R}$ & - \\
\hline Corethron criophilum & $\mathrm{C}$ & $\mathrm{C}$ & Cylindrotheca closterium & $\mathrm{C}$ & $\mathrm{R}$ \\
\hline Leptocylindrus danicus & $\mathrm{C}$ & $\mathrm{R}$ & Nitzschia seriata & $\mathrm{C}$ & $\mathrm{C}$ \\
\hline Coscinodiscus sp. & A & $\mathrm{A}$ & N. pelagica & $\mathrm{R}$ & - \\
\hline Asteromphalus heptactis & $\mathrm{R}$ & - & N. delicatissima & $\mathrm{C}$ & $\mathrm{R}$ \\
\hline Dactyliosolen antarcticus & $\mathrm{C}$ & $\mathrm{R}$ & N. lineata & A & $\mathrm{R}$ \\
\hline Guinardia flaccida & - & $\mathrm{C}$ & N. kerguelensis & $\mathrm{C}$ & - \\
\hline Rhizosolenia alata & $\mathrm{C}$ & A & & & \\
\hline R. alata $\mathrm{f}$. indica & $\mathrm{R}$ & $\mathrm{R}$ & Dinoflagellates & & \\
\hline R. alata f. gracillima & - & $\mathrm{C}$ & Prorocentrum micans & $\mathrm{C}$ & $\mathrm{C}$ \\
\hline R. curvata & A & A & P. dentatum & $\mathrm{C}$ & $\mathrm{R}$ \\
\hline R. delicatula & $\mathrm{R}$ & $\mathrm{C}$ & P. scutellum & $\mathrm{C}$ & $\mathrm{R}$ \\
\hline R. stolterfothii & $\mathrm{R}$ & A & P. gracile & $\mathrm{R}$ & - \\
\hline Bacteriastrum sp. & $\mathrm{R}$ & - & Dinophysis ovum & $\mathrm{R}$ & - \\
\hline Chaetoceros affinis & - & $\mathrm{R}$ & Dinophysis sp. & - & $\mathrm{C}$ \\
\hline C. atlanticus & A & $\mathrm{C}$ & Gymnodinium sp. & C & $\mathrm{C}$ \\
\hline C. criophilus & $\mathrm{R}$ & - & G. arcticum & $\mathrm{R}$ & - \\
\hline C. didymus & $\mathrm{C}$ & $\mathrm{R}$ & Protoperidinium breve & - & $\mathrm{R}$ \\
\hline C. didymus v. protuberans & $\mathrm{R}$ & - & P. depressum & $\mathrm{R}$ & $\mathrm{R}$ \\
\hline C. peruvianus & $\mathrm{C}$ & A & Ceratium fusus & $\mathrm{R}$ & - \\
\hline C. radicans & $\mathrm{D}$ & A & C. tripos & $\mathrm{R}$ & $\mathrm{C}$ \\
\hline C. socialis & $\mathrm{R}$ & - & C. pentagonum & $\mathrm{R}$ & $\mathrm{R}$ \\
\hline Dytilum sol & $\mathrm{R}$ & $\mathrm{C}$ & C. furca & $\mathrm{C}$ & $\mathrm{C}$ \\
\hline Delphineis karstenii & $\mathrm{R}$ & - & Oxytoxum mitra & $\mathrm{R}$ & $\mathrm{R}$ \\
\hline Fragilaria granulata & $\mathrm{C}$ & $\mathrm{C}$ & O. variabile & $\mathrm{R}$ & - \\
\hline Striatella delicatula & - & $\mathrm{R}$ & Podolampas bipes & $\mathrm{R}$ & - \\
\hline Synedra indica & $\mathrm{R}$ & $\mathrm{C}$ & P. elegans & $\mathrm{R}$ & - \\
\hline S. ossiformis & $\mathrm{R}$ & - & & & \\
\hline Thalassionema nitzschioides & - & $\mathrm{C}$ & Silicoflagellates & & \\
\hline Thalassiotrix longissima & A & A & Dictyocha speculum & A & $\mathrm{R}$ \\
\hline
\end{tabular}

1988). A bloom of Chaetoceros neglectum was recorded in March 1981 (Fryxell et al. 1981) while Rhizosolenia curvata was found in bloom stage during May 1983 (Allanson et al. 1985). Bloom concentrations of the silicoflagellate Dictyocha speculum were also found in November 1983 (Boden 1988). This typical composition is well reflected in the structure of the phytoplankton bloom investigated in April 1985 (Table 6). An account of the available information on zooplankton feeding responses to the qualitative characteristics of this food source is given below.

Limacina sp., like all thecosomatous pteropod molluscs, is a ciliary-mucus feeder ingesting primarily phytoplankton, although larger species also capture planktonic protozoa including tintinnids, foraminifera and radiolarians (Gilmer 1974). Particles less than $5 \mu \mathrm{m}$ account for the largest percentage by number of all food particles. Ingestion of larger particles appears to be limited by the dimensions of the ciliated grooves through which the food must pass to enter the mouth (Gilmer 1974). Thus, it seems unlikely that Limacina sp. can effectively ingest large cells like Rhizosolenia spp. or the long, spiny chains of Chaetoceros spp. that dominate the phytoplankton community of the Prince Edward Islands. Indeed, Morton (1954) reported that large cells of Chaetoceros with long bristles were rejected as unwieldy by Limacina helicoides in Antarctic waters.

The most important copepods of the zooplankton community of the Prince Edward Island seas are Calanus simillimus, Clausocalanus brevipes and Metridia gerlachei (Table 2). C. simillimus and C. brevipes belong to families (Calanidae and Pseudocalanidae) which are well known for their ecological importance as phytoplankton grazers, while $M$. gerlachei is an omnivore (Schnack 1983). In incubation experiments, copepods feeding on naturally occurring phytoplankton tend to ingest preferentially the dominant sizeclass (biomass peak) regardless of size (Poulet 1974, Conover 1978, Huntley 1981). Selective feeding on the larger particles has also been observed, especially in artificial mixtures (Haq 1967, Frost 1977, Gifford et al. 
1981). However, it has been shown that copepods are able to select particulate food according to its quality and can discriminate particles after collection by either ingesting or rejecting them (Poulet \& Marsot 1978, Donaghay \& Small 1979, Koehl \& Strickler 1981, Huntley et al. 1983). A number of studies have indicated that the phytoplankton taxa which dominate blooms at the Prince Edward Islands are usually rejected by pelagic copepods. Although some degree of copepod grazing on Chaetoceros spp. has been shown (Longhurst 1967, Poulet 1974, Schnack 1979, 1985), these diatoms are often not readily consumed because their thick spiny filaments act as a deterrent (Parsons et al. 1967, Hargrave \& Geen 1970, Voronina \& Sukhanova 1977, Corkett \& McLaren 1978). C. radicans, the most common species around the Prince Edward Islands, forms long chains and even mats, and has one of the thickest spine structures in the genus. Similarly, although some small species of Rhizosolenia can be ingested (Paffenhöfer et al, 1982, Price \& Paffenhöfer 1986), these diatoms are usually poorly represented in the gut contents of pelagic copepods and are not eaten in selective feeding experiments (Bogorov 1967, Haq, 1967, Marshall 1973). Cells of $R$. curvata are very long (up to $700 \mu \mathrm{m}$ ), cylindrical and often aggregate in chains or 'rafts' of individuals of varying size. The cell wall is robust and moderately silicified (Boden \& Reid 1989). The silicoflagellate Dictyocha speculum has an internal skeleton of conspicuous siliceous spicules and like all silicoflagellates is known not to be a staple component of copepod diets (Marshall 1973, Raymont 1983).

During April/May 1989, the euphausiids were the only group among the zooplankton examined to show a preferential selection for net phytoplankton, as well as nanoplankton (Table 1). The subantarctic Euphausia vallentini is the dominant species in the area and, like the Antarctic krill E. superba, is regarded as a typical herbivorous filter-feeder with well-developed maxillary setae (Mauchline 1980). Euphausia species are known to ingest efficiently particles in a wide size range because of the peculiar structure of their feeding basket (see McClatchie \& Boyd 1983 for E. superba). They graze moderately on large Rhizosolenia cells and on chains of Chaetoceros (Parsons et al. 1967, Pavlov 1971, Kawamura 1981), but Stuart (1989) has recently shown that in a diatomdominated upwelling system E. lucens prefers the less abundant dinoflagellates. These euphausiids also have the ability to switch to carnivorous feeding when sufficient zooplankton prey is available (Mauchline 1980, Price et al. 1988). Foraminifera were a staple component in the guts of E. vallentini in April/May 1989 at the Prince Edward Islands (Stuart pers. comm.). Diatom fragments along with tintinnids and radiolarians were poorly represented in the gut samples. Species of the genus Thysanoessa, represented in the Prince Edward Archipelago by $T$. vicina, have elongated 2nd thoracic legs of use in predatory feeding and are mixed feeders, but mainly carnivorous (Mauchline 1980).

Similarly, the morphology of the mouthparts of the ostracods Conchoecia spp. suggests that they are generally predatory or detritivores. Copepod remains are often predominant in their stomachs but phytoplankton is also ingested and is probably collected by sticky secretions of the marginal glands of the carapace, or by the mandibular palps (Iles 1961, Angel 1981). Diatoms and silicoflagellates have been recorded in abundance in the stomach contents and faecal pellets of some species (Angel 1968). Very high levels of plant pigments were found in the gut of Conchoecia sp. during the 1985 phytoplankton bloom (Fig. 2). However, due to the scarce representation of this ostracod within the zooplankton community, its grazing impact was very limited during both the 1985 and the 1989 surveys (Table 5).

The biochemical composition of phytoplankton is also important to the food selection of zooplankton grazers. Recent studies report that many diatoms do not represent a food source of high nutritional value, relative to other planktonic groups. Hitchcock (1982) has shown that dinoflagellates contain 3 to 5 times more calories than diatoms per unit volume. Furthermore, comparative analysis on the presence of unsaturated fatty acids in species of dinoflagellates, diatoms, ciliates and autotrophic nanoflagellates (Ben-Amotz et al. 1987, Claustre et al. 1989) have indicated that some diatoms (Chaetoceros sp. and Nitzchia sp.) have the lowest levels among the taxa examined. Unsaturated fatty acids apparently play a dominant nutritional role for zooplankton grazers (Holz 1981, Claustre et al. 1989). Thus, the observed negative selection of most zooplankton for the large diatoms, and their preference for nanoplankton, could also have a sound energetic basis. Nanoplankton largely dominates the phytoplankton biomass of the Southern Ocean, where it usually constitutes 60 to $85 \%$ of the total (Weber \& El Sayed 1987). Also, the biomass contribution of diatoms to the nanoplankton decreases dramatically, compared to the netplankton. The use of sequential epifluorescence and electron microscopy techniques has shown that most of the nanophytoplankton is composed of autotrophic flagellates (Estep et al. 1984, Hoepffner \& Haas 1990). Then, the ability of zooplankton to select preferentially the smaller cells may result in an increase in their conversion efficiency, by ingesting food of higher nutritional value.

The potential significance of the poor utilization of phytoplankton blooms by the mesozooplankton of the 
Prince Edward Island seas cannot be overemphasized. Any primary production that is not consumed by these grazers is available to the other parts of the marine ecosystem, like the microheterotrophic food web and the benthic filter-feeders. Phagotrophic protozoa can graze most of the primary production in open oceanic waters dominated by pico- and nanoplankton (Sherr et al. 1986). But, on account of size differences, it is unlikely that the bulk of these neritic blooms of large diatoms are significantly consumed by microheterotrophs. Their most probable fate is to sink out of the photic zone, thus providing an important input of biomass into the benthic subsystem. Sedimentation of spring diatom blooms, in the absence of overwintering populations of zooplankton grazers, is well documented for many coastal areas (Conover \& Mayzaud 1984, Kuparinen et al. 1985). There is also evidence that large portions of phytoplankton biomass sediment out even in the presence of large overwintering zooplankton populations (Dagg et al. 1982, Smetacek 1984). In Antarctic waters, mass sinking of diatom blooms has been shown by means of moored sediment traps in the Bransfield Strait (Bodungen et al. 1986) and in Breid Bay (Fukuchi et al. 1988). Bodungen et al. (1986) found that mass sedimentation occurred in conjunction with formation of diatom resting spores, which contributed about two-thirds of the total phytoplankton cells in their trap collections. Resting spores, particularly of Chaetoceros radicans in bloom stage, have often been found in the phytoplankton of the Prince Edward Islands (Fryxell et al. 1981, Boden \& Reid 1989). Spore concentrations of nearly 100 per chain of 8 or 9 cells of $C$. radicans have been recorded by Boden \& Reid (1989). This and the relatively high sedimentation rates of particulate organic matter observed in the area (Bailey pers. comm.), appear to confirm the hypothesis that sedimentation in the Prince Edward Archipelago causes a greater loss of phytoplankton biomass from the surface layer than zooplankton grazing. This would also explain the large biomass of benthic filter-feeders observed on the islands' shelf (Perissinotto et al. 1990a).

Acknowledgements. I thank R. J. Conover, C. T. Taggart and C. D. McQuaid for their support and constructive criticism throughout this study. Funding was provided by the South African Department of Environment Affairs, through the Committee for Antarctic Research (SACAR), and by a Dalhousie University Fellowship. The co-operation of the masters, officers and crews of the SA 'Agulhas' is gratefully acknowledged. The technological support and expertise of A. Robertson, A. Hirst, A. Kemp and M. Van der Berg of the Sea Fisheries Research Institute, Cape Town, facilitated the research beyond description. Assistance at sea was also provided by B. Boden, A. Arnott, C. Attwood and R. Van Ballegooyen.

\section{LITERATURE CITED}

Allanson, B. R., Boden, B. P., Parker, L. D., Duncombe Rae, C, M. (1985). A contribution to the oceanology of the Prince Edward Islands. In: Siegfried, W. R., Condy, P. R., Laws, R. M. (eds.) Antarctic nutrient cycles and food webs. Springer-Verlag, Berlin, p. 38-45

Angel, M. V. (1968). The thermocline as an ecological boundary. Sarsia 34: 299-312

Angel, M. V. (1981). Ostracoda. In: Boltovskoy, D. (ed. ) Atlas del zooplancton del Atlántico sudoccidental. Instituto Nacional de Investigacioń y Desarrollo Pesquero, Mar del Plata, p. 543-585

Baars, M. A., Helling, G. R. (1985). Methodical problems in the measurements of phytoplankton ingestion rate by gut fluorescence. Hydrobiol. Bull. 19: 81-88

Ben-Amotz, A., Fishler, R., Schneller, A. (1987). Chemical composition of dietary species of marine unicellular algae and rotifers with emphasis on fatty acids. Mar. Biol. 95: 31-36

Boden, B. P. (1988). Observations of the island mass effect in the Prince Edward Archipelago. Polar Biol. 9: 61-68

Boden, B. P., Parker, L. D. (1986). The plankton of the Prince Edward Islands. Polar Biol. 5: 81-93

Boden, B. P., Reid, F. M. H. (1989). Marine plankton diatoms between Cape Town and the Prince Edward Islands (SW Indian Ocean). S. Afr. J. Antarct. Res. 19: 2-47

Bodungen, B. von, Smetacek, V. S., Tilzer, M. M., Zeitzschel, B. (1986). Primary production and sedimentation during spring in the Antarctic Peninsula region. Deep Sea Res. 33: 177-194

Bogorov, V. G. (1967). Biological transformation and exchange of energy and substances in the ocean. Oceanology 7 : 649-665

Claustre, H., Marty, J. C., Cassiani, L., Dagaut, J. (1989). Fatty acid dynamics in phytoplankton and microzooplankton communities during a spring bloom in the coastal Ligurian Sea: ecological implications. Mar. microb. Food Webs 3: $51-66$

Conover, R. J. (1978). Feeding interactions in the pelagic zone. Rapp. P.-v. Réun. Cons. Int. Explor. Mer 173: 66-76

Conover, R. J., Mayzaud, P. (1984). Utilization of phytoplankton by zooplankton during the spring bloom in a Nova Scotia inlet. Can. J. Fish. Aquat. Sci. 41: 232-244

Conover, R. J., Durvasula, R., Roy, S., Wang, R. (1986). Probable loss of chlorophyll-derived pigments during passage through the gut of zooplankton and some of the consequences. Limnol. Oceanogr. 31: 878-887

Corkett, C. J., McLaren, I. A. (1978). The biology of Pseudocalanus. Adv. mar. Biol. 15: 1-231

Dagg, M. J. (1983). A method for the determination of copepod feeding rates during short time intervals. Mar. Biol. 75: 63-67

Dagg, M. J., Vidal, J., Whitledge, T. E., Iverson, R. L., Goering, J. J. (1982). The feeding, respiration and excretion of zooplankton in the Bering Sea during the spring bloom. Deep Sea Res. 29: 45-63

Dagg, M. J., Walser, W. E. Jr (1987). Ingestion, gut passage and egestion by the copepod Neocalanus plumchrus in the laboratory and in the subarctic Pacific Ocean. Limnol. Oceanogr. 32: 178-188

Dam, H. G., Peterson, W. T. (1988). The effect of temperature on the gut clearance rate constant of planktonic copepods. J. exp. mar. Biol. Ecol. 123: 1-14

Donaghay, P. L., Small, L. F. (1979). Food selection capabilities of the estuarine copepod Acartia clausi. Mar. Biol. 52: $137-146$ 
El Sayed, S. Z., Stockwell, D. A., Reheim, H. A., Taguchi, S., Meyer, M. A. (1979). On the productivity of the southwestern Indian Ocean. Com. natn. fr. Rech. antarct. 44: 83-110

Estep, K. W., Davis, P. G., Hargraves, P. E., Sieburth, J. McN. (1984). Chloroplast containing microflagellates in natural populations of North Atlantic nanoplankton, their identification and distribution; including a description of five new species of Chrysocromulina (Prymnesiophyceae). Protistologica 20: 613-634

Frost, B. W. (1977). Feeding behaviour of Calanus pacificus in mixtures of food particles. Limnol. Oceanogr. 22: 472-491

Fryxell, G. A., Villareal, T. A., Doucette, G. J. (1981). Diatom resting spores and Agulhas collections. Antarct. J. U.S. 16: $128-130$

Fukuchi, M., Hattori, H., Sasaki, H., Hoshiai, T. (1988). A phytoplankton bloom and associated processes observed with a long-term moored system in Antarctic waters. Mar. Ecol. Prog. Ser. 45: 279-288

Gifford, D. N., Bohrer, R. N., Boyd, C. M. (1981). Spine on diatoms: do copepods care? Limnol. Oceanogr. 26: 971-981

Gilmer, R. W. (1974). Some aspects of feeding in thecosomatous pteropod molluscs. J. exp. mar. Biol. Ecol. 15: 127-144

Haq, S. M. (1967). Nutritional phisiology of Metridia lucens and $M$. longa from the Gulf of Maine. Limnol. Oceanogr. 12: $40-51$

Hargrave, B. T., Geen, G. H. (1970). Effects of copepod grazing on two natural phytoplankton populations. J. Fish. Res. Bd Can. 27: 1395-1403

Head, E. J. H., Harris, L. R. (1987). Copepod feeding patterns before and during a spring bloom in Bedford Basin, Nova Scotia. Mar. Ecol. Prog. Ser. 40: 221-230

Hitchcock, G. L. (1982). A comparative study of the sizedependent organic composition of marine diatoms and dinoflagellates. J. Plankton Res. 4: 363-377

Hoepffner, N., Haas, L. W. (1990). Electron microscopical studies of nanoplankton from the North Pacific Central Gyre. J. Phycol. 26: 421-439

Holz, G. G. Jr (1981). Non-isoprenoid lipids and lipid metabolism of marine flagellates. In: Levandovsky, M., Hutner, S. H. (eds.) Biochemistry and physiology of protozoa, Vol. 4. Academic, New York, p. 301-322

Huntley, M. E. (1981). Nonselective, nonsaturated feeding by three calanid copepod species in the Labrador Sea. Limnol. Oceanogr. 12: 40-51

Huntley, M. E., Barthel, K.-G., Star, J. L. (1983). Particle rejection by Calanus pacificus: discrimination between similarly sized particles. Mar. Biol. 74: 151-160

les, E. J. (1961). The appendages of the Halocyprididae. 'Discovery' Rep. 31: 299-326

Kawamura, A. (1981). Food habits of Euphausia superba and the diatom community. In: El Sayed, S. Z. (ed.) Biomass, Vol. 2, Selected contributions to the Woods Hole conference on living resources of the Southern Ocean. Cambridge University Press, Cambridge, p. 65-68

Kiørboe, T., Tiselius, P. (1987). Gut clearance and pigment destruction in a herbivorous copepod, Acartia tonsa, and the determination of in situ grazing rates. J. Plankton Res. 9: $525-534$

Koehl, M. A. R., Strickler, J. R. (1981). Copepod feeding currents: food capture at low Reynolds number, Limnol. Oceanogr. 26: 1062-1073

Kott, P. (1953). Modified whirling apparatus for subsampling of plankton. Aust. J. Freshwat. Res, 4: 387-393

Kuparinen, J., Leppänen, J.-M., Sarvala, J., Sundberg, A., Virtanen, A. (1985). Production and utilization of organic matter in a Baltic ecosystem off Tvärminne, SW coast of
Finnland. Rapp. P,-v. Réun. Cons. int. Explor. Mer 183: 180-192

Longhurst, A. R. (1967). Diversity and trophic structure of zooplankton communities in the California Current. Deep Sea Res. 14: 393-408

Mackas, D., Bohrer, R. (1976). Fluorescence analysis of zooplankton gut contents and an investigation of diel feeding patterns. J. exp. mar. Biol. Ecol. 25: 77-85

Marshall, S. M. (1973). Respiration and feeding in copepods. Adv. mar. Biol. 11: 57-120

Mauchline, J. (1980). The biology of mysids and euphausiids. Adv. mar. Biol. 18: 1-681

McClatchie, S., Boyd, C. M. (1983). Morphological study of sieve efficiencies and mandibular surfaces in the Antarctic krill, Euphausia superba. Can. J. Fish. Aquat. Sci. 40: 955-967

Morton, J. E. (1954). The biology of Limacina retroversa. J. Mar. biol. Ass. U.K. 33: 297-312

Paffenhöfer, G. A., Strickler, J. R., Alcaraz, M. (1982). Suspension-feeding by herbivorous calanoid copepods: a cinematographic study. Mar. Biol. 67: 193-199

Parsons, T. R., Le Brasseur, R. J., Fulton, J. D. (1967). Some observations on the dependence of zooplankton grazing on the cell size and concentration of phytoplankton blooms. J. oceanogr. Soc. Japan 23: 10-17

Pavlov, V Ya. (1971). On the qualitative composition of the food of Euphausia superba Dana. Proc. All-Union Res. Inst. Mar. Fish. Oceanogr. 86: 42-54. Fish. Res. Bd Can. Transl. Serv. 2953: 1-16

Perissinotto, R. (1989). The structure and diurnal variations of the zooplankton of the Prince Edward Islands: implications for the biomass build-up of higher trophic levels. Polar Biol. 9: 505-510

Perissinotto, R., Allanson, B. R., Boden, B. P. (1990a). Trophic relations within the island seas of the Prince Edward Archipelago (Southern Ocean). In: Barnes, M., Gibson, R. (eds.) Trophic relationships in the marine environment. 24th Eur. Mar. Biol. Symp. Aberdeen University Press, Aberdeen, p. 296-314

Perissinotto, R., Boden, B. P. (1989). Zooplankton-phytoplankton relationships at the Prince Edward Islands during April/May 1985 and 1986. S. Afr. J. Antarct. Res. 19: 26-30

Perissinotto, R., Duncombe Rae, C. M. (1990). Occurrence of anticyclonic eddies on the Prince Edward Plateau (Southern Ocean): effects on phytoplankton biomass and production. Deep Sea Res. 37: 777-793

Perissinotto, R., Duncombe Rae, C. M., Boden, B. P., Allanson, B. R. (1990b). Vertical stability as a controlling factor of the marine phytoplankton production at the Prince Edward Archipelago (Southern Ocean). Mar. Ecol. Prog. Ser. 60: 205-209

Peterson, W. T., Painting, S. J., Hutchings, L. (1990). Diel variations in gut pigment content, diel vertical migration and estimates of grazing impact for copepods in the southern Benguela upwelling region, in October 1987. J. Plankton Res. 12: 259-281

Poulet, S. A. (1974). Seasonal grazing of Pseudocalanus minutus on particles. Mar. Biol. 25: 109-123

Poulet, S. A., Marsot, P. (1978). Chemosensory grazing by marine calanoid copepods (Arthropoda: Crustacea). Science 200: 1403-1405

Price, H. J., Boyd, K. R., Boyd, C. M. (1988). Omnivorous feeding behavior of the Antarctic krill Euphausia superba. Mar. Biol. 97: 67-77

Price, H. J., Paffenhöfer, G.-A. (1986). Effects of concentration on the feeding of a marine copepod in algal monocultures and mixtures. J. Plankton Res, 8: 119-128 
Raymont, J. E. G. (1983). Plankton and productivity in the oceans, Vol. 2, Zooplankton, 2nd edn. Pergamon, Oxford, p. 824

Schnack, S. B. (1979). Feeding of Calanus helgolandicus on phytoplankton mixtures. Mar. Ecol. Prog. Ser. 1: 41-47

Schnack, S. B. (1983). Feeding of two Antarcic copepod species (Calanus propinquus and Metridia gerlachei) on a mixture of centric diatoms. Polar Biol. 2: 63-68

Schnack S. B. (1985). Feeding by Euphausia superba and copepod species in response to varying concentrations of phytoplankton. In: Siegfried, W. R., Condy, P. R., Laws, R. M. (eds.) Antarctic nutrient cycles and food webs. Springer-Verlag, Berlin, p. 311-323

SCOR/UNESCO Working Group 17 (1966). Determination of photosynthetic pigments in seawater. UNESCO Monographs on Oceanographic Methodology, Vol. 1. UNESCO, Paris, p. 69

Sherr, E. B., Sherr, B. F., Paffenhöfer, G.-A. (1986). Phagotrophic protozoa as food for metazoans: a 'missing' trophic link in marine pelagic food webs? Mar. microb. Food Webs 1: $61-80$

Smetacek, V. (1984). The supply of food to the benthos. In: Fasham, M. J. R. (ed.) Flows of energy and materials in marine ecosystems. Plenum, New York, p. 517-547

This article was submitted to the editor
Strickland, J. D. H., Parsons, T. R. (1968). A practical handbook of seawater analysis. Bull. Fish. Res. Bd Can. 167: $1-311$

Stuart, V. (1989). Observations on the feeding of Euphausia lucens on natural phytoplankton suspensions in the southern Benguela upwelling region. Cont, Shelf Res. 9: 1017-1028

Tsuda, A., Nemoto, T. (1987). The effect of food concentration on the gut clearance time of Pseudocalanus minutus Kroyer (Calanoida: Copepoda). J. exp. mar. Biol. Ecol. 107: 121-130

Voronina, N. M., Sukhanova, I. N. (1977). Composition of food of massive species of herbivorous Antarctic copepods. Oceanology 16: 614-616

Wang, R., Conover, R. J. (1986). Dynamics of gut pigment in the copepod Temora longicornis and the determination of in situ grazing rates. Limnol. Oceanogr. 31: 867-877

Weber, L., El Sayed, S. Z. (1987). Contributions of the net-, nano- and picoplankton to the phytoplankton standing crop and primary productivity in the Southern Ocean. J. Plankton Res. 9: 973-994

Willason, S. W., Cox, J. L. (1987). Diel feeding, laminarinase activity and phytoplankton consumption by euphausiids. Biol. Oceanogr. 4: 1-24

Manuscript first received: August 27, 1991

Revised version accepted: December 17, 1991 